\title{
都市における住宅の消費エネルギー推計のための世帯推計モデル およびエネルギーマップに関する基礎的研究 \\ A STUDY ON HOUSEHOLD ESTIMATION MODEL FOR PREDICTING ENERGY CONSUMPTION OF DWELLINGS AND ENERGY MAP IN AN URBAN AREA
}

\author{
木 村 竜士*，松本 博** \\ Ryushi KIMURA and Hiroshi MATSUMOTO
}

\begin{abstract}
For estimating the energy consumption of a city that consists of numerous different sizes and types of building, it is necessary to estimate the distribution of the energy consumption of buildings in the urban area. The objective of this study is to estimate the household number and household composition of 22 patterns of household life cycle matrix using the co-hort factor method based on the population and regional econometric models. The case study was done for Toyohashi city, Japan. The energy consumption in the residential area was expected to be decreased for 50 years due to the decrease of population and high efficient energy supply system. The estimated household number was determined by the regional econometric model. The population would have decreased by approximately $20 \%$ compared with the present population in the central area around Toyohashi station and the population in suburb area would have slightly increased by $1.2 \%$. The total energy consumption of the energy efficient house was expected to be decreased by $17.5 \%$ compared with the present level.
\end{abstract}

Keywords: Energy consumption, Household estimation model, Co-hort factor Method, Regional econometric model, Energy map エネルギー消費,世帯推計モデル,コーホート要因法,地域計量経済モデル,エネルギーマップ

\section{1. はじめに}

未来の持続可能な社会に向けて生活の質を低下させることなく エネルギー、天然資源および環境負荷を低減するためのシナリオを 提示するためには、都市・建築における現在のエネルギーフローを 調査・分析し、将来の動向を予測・評価することが極めて重要であ る。建物単体や建築材料のライフサイクル・アセスメント（Life Cycle Assessment、 LCA）に関しては、既に様々な評価ツールや それを用いたケーススタディが数多くなされている。予測に関して は、人口的、経済・社会的、環境的および地理的など様々な要因が 個々の分野で詳細な予測シミュレーションが行われている。しかし、 実際のエネルギー消費動向は、それら全ての要因が複雑に相互に影 響し合い変動しているため、それらを包括的に扱う予測システムを 構築しなければならない。そのモデルにより予測を行い、その結果 を元に総合的評価をする必要がある。

特に住宅は、業務ビル、大規模商業建築や工場建築と比べ、人口 動向、経済動向や立地条件に影響を受け空間的な変動が大きい。そ のため、その因果関係を説明する方程式を立て、推計された世帯エ ネルギー分布を空間的に把握することにより、住宅の集中立地型お
よび分散立地型などの立地条件に適した省エネルギー対策が行え、 地域冷暖房システム導入の検討など改善案をより具体的に提案す ることが出来る。

経済モデルによる環境負荷予測を行った研究事例として、藤野ら 1) は、多様なアジア地域における、将来の各国レベルの経済活動量, エネルギー需給・水需給・環境污染物質排出量等を予測するため,一 般均衡分析による過去のトレンド分析に主眼をおいたAIM-Trend モデルを開発した。しかし、一般均衡分析は、設定された各産業の 財の価格への影響度を評価する場合には優れているが、出生率など の価格による代替が難しい変数を設定し、地域固有の経済動向と関 連する方程式を立てることは難しい。

そこで、地域の統計データによる経済動向が反映される経済モデ ルとして、地域計量経済モデルがある。地域計量経済モデルによる 研究事例として、山口ら2）、3）は、多地域連動型計量経済モデルによ り都市システムの構築や自動車交通による環境負荷や経済に与え る影響を評価した。これらの地域計量経済モデルは、対象地域の経 済データのみならず、人口や土地面積などの地域の固有統計データ を基に地域固有の構造方程式を構築・分析している。
* 豊橋技術科学大学大学院環境生命工学専攻 博士課程·修士 (工学)

** 豊橋技術科学大学建設工学 教授. 工博
Graduate Student, Life and Environmental Engineering, Graduate School of Toyohashi University of Technology, M. Eng.

Prof., Dept. of Architecture and Civil Engineering, Toyohashi University of Technology, Dr. Eng. 
エネルギーマップ作成に関する研究事例として、酒井ら $\left.{ }^{4}\right) 、$ 草㺫 ら5）がそれぞれ地理情報システム（G I S ）により、500m角メッ シュ、 $250 \mathrm{~m}$ 角メッシュにより対象地域をメッシュ化し、地域エネ ルギー消費量の空間的分布を提示し分析を行った。しかし、その精 度のメッシュ角の場合、メッシュ内に存在する建物の推計を正確に 行うことができないため、さらに細かいメッシュにより都市を再現 する必要がある。

筆者ら6)は、都市のエネルギーフローモデルの開発にあたり、シ ステムダイナミクス法を用いて、ローレンスクラインマクロ経済モ デル、コーホート変化率法を用いた人口推計モデルを開発し、それ らのモデルから世帯推計を行い、生活スケジュール7)およびライフサ イクルマトリクス8 ${ }^{8}$ 考慮した 4 パターンの家族構成別世帯消費エネ ルギー量を世帯数に掛けることで豊橋市全域の住宅部門における消 費エネルギー量を算出し、さらに豊橋市のオフィス建築における消費 エネルギー量を、産業連関表を用いて、物量表をエネルギー原単位に 変換することで算出した9)。

本研究は、人口動向、経済動向や地図データを包括的に扱う都市 におけるエネルギーフローの新しい予測システムを提案し、世帯構成 員の変化を考慮したコーホート要因法による人口推計モデルと地域 計量経済モデルから世帯消費エネルギ一量の長期予測を行い、そのエ ネルギー量を空間的に把握するために $10 \mathrm{~m}$ 角グリッドというこれま での関連研究にない詳細なエネルギーマップモデルに反映させるこ とで世帯の変動に伴うエネルギー分布の長期変動を把握することが 出来るシステムモデルの開発を目的としている。

\section{2. システムモデルの概要}

住宅エネルギー消費量予測のためのシステムモデルの概要を図 1 に示す。都市の住宅部門におけるエネルギーマップを最終的に出力す るために、住宅の世帯構成別エネルギー消費量 22 パターンを算出し、 地域計量経済モデルにより新築される世帯数を、人口推計モデルによ り既存世帯数の増減をそれぞれ算出し、対象地域内の世帯総数を得る。 また、計量経済モデルと人口推計モデル間のインターフェースとして、

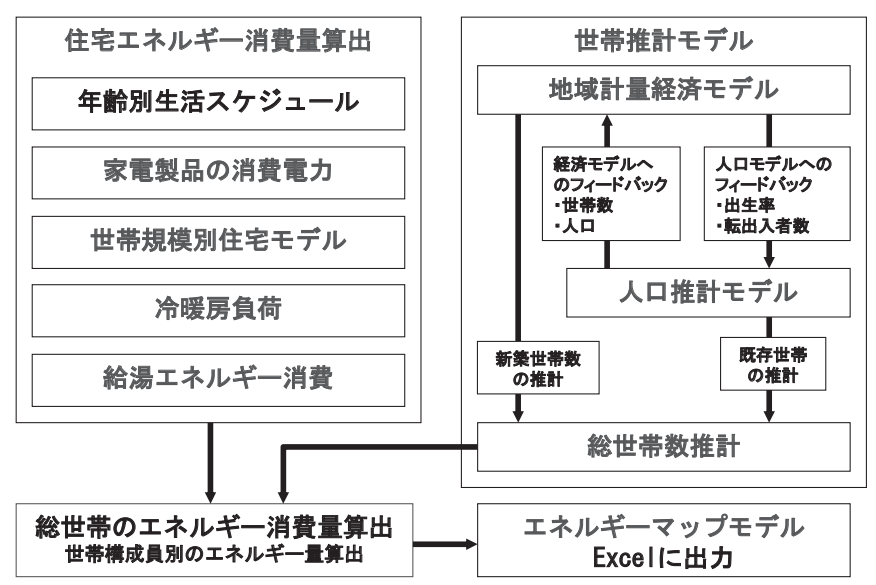

図 1 システムモデル概要
地域計量経済モデルで推計された合計特殊出生率注 1)、転入・転出人 口が人口推計モデルへフィードバックされ、人口推計モデルで推計さ れた人口や世帯数が計量経済モデルの変数としてフィードバックさ れる。それをExcel (Microsoft社製) で作成した $10 \mathrm{~m}$ 角メッシュの 詳細な地理データに消費エネルギー量別にプロットすることで、推計 年度毎の消費エネルギー量の動向を平面的に把握できる。特に住宅地 は、集中立地型もしくは分散立地型の違いによる消費エネルギー分布 があるため、それをエネルギーマップにより把握することが出来る。

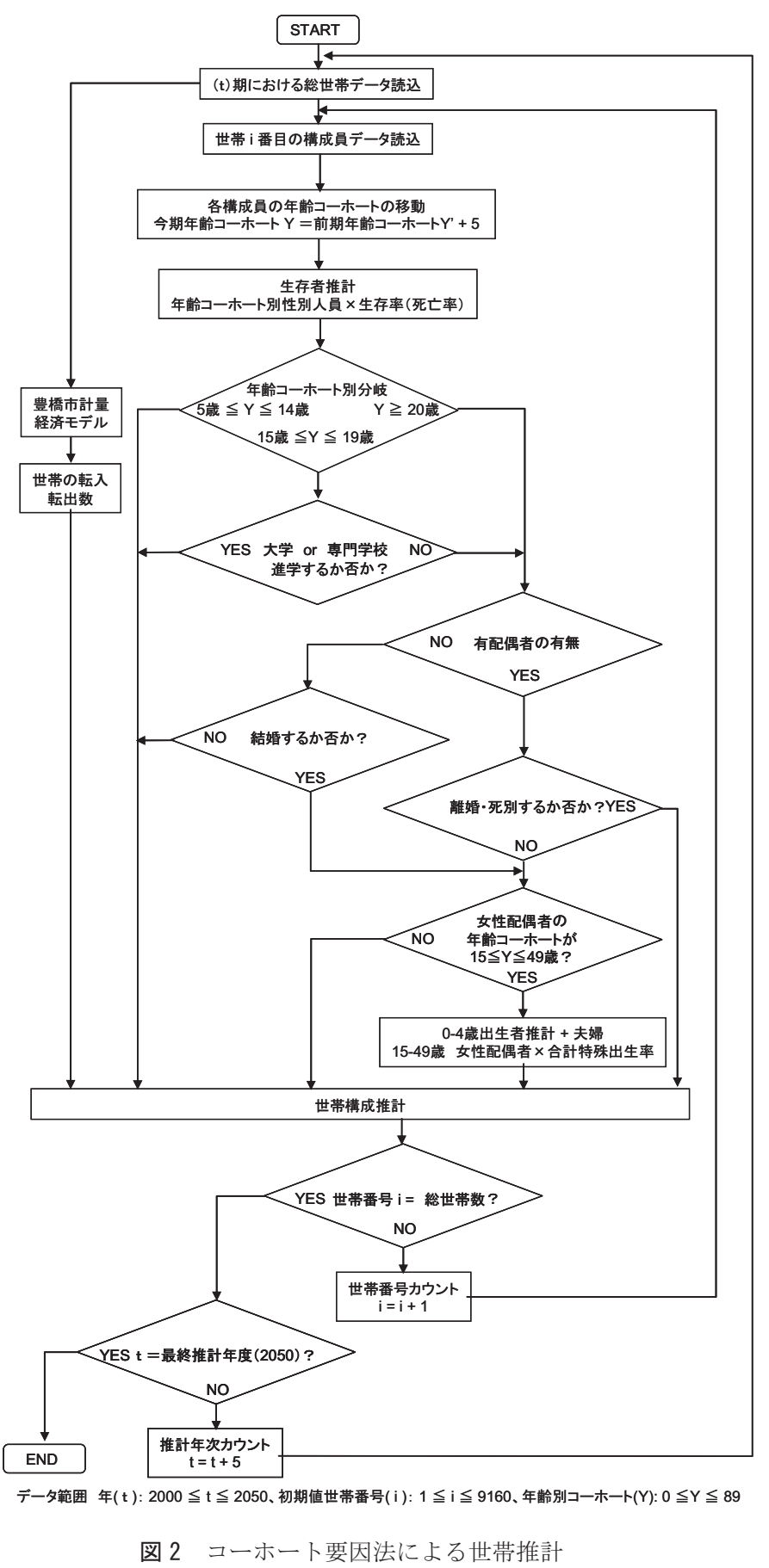


対象地域は、愛知県豊橋市の豊橋駅周辺地域 $(24,077$ 人 (9160 戸) $)$ とした。選定理由として、地域計量経済モデルを作成するに当り、必 要な一次統計データが比較的得やすい最小限の都市規模であるため、 それ以上の都市規模に対しても適用可能と考えられる。

\section{3.コーホート要因法を用いた世帯推計}

\section{1 モデルの概要}

コーホート要因法のフローチャートを図 2 に示す。本来、コーホー 卜要因法は、人口増減を決定する要因である出生、死亡、社会移動を

表 1 人口推計に用いる計算条件

\begin{tabular}{|c|c|c|c|c|c|c|c|}
\hline \multirow{20}{*}{ 男 } & $\begin{array}{c}\text { 年齢(5歳階級) } \\
\text { 未姚率(\%) }\end{array}$ & $\frac{0-4}{1000}$ & $\frac{5-9}{1000}$ & $\frac{10-14}{1000}$ & \begin{tabular}{rl|}
$15-19$ \\
992
\end{tabular} & $\frac{20-24}{913}$ & $\frac{25-29}{647}$ \\
\hline & 有配偶率 (\%) & 0.0 & 0.0 & 0.0 & 0.8 & 8.5 & 34.0 \\
\hline & 死別率 $(\%)$ & 0.0 & 0.0 & 0.0 & 0.0 & 0.0 & 0.0 \\
\hline & 離別率 (\%) & 0.0 & 0.0 & 0.0 & 0.0 & 0.2 & 1.3 \\
\hline & 死亡率 (\%) & 0.1 & 0.1 & 0.3 & 0.4 & 3.4 & 0.4 \\
\hline & 大学進学率 (\%) & - & - & - & 78.7 & - & - \\
\hline & 年齢(5歳階級) & $30-34$ & $35-39$ & $40-44$ & $45-49$ & $50-54$ & $55-59$ \\
\hline & 未婚率 (\%) & 39.2 & 23.8 & 17.9 & 14.2 & 10.2 & 5.6 \\
\hline & 有配偶率 (\%) & 58.5 & 71.7 & 80.0 & 80.0 & 82.9 & 86.7 \\
\hline & 死別率 (\%) & 0.1 & 0.1 & 0.3 & 0.6 & 1.2 & 2.0 \\
\hline & 離別率(\%) & 2.2 & 3.1 & 3.6 & 4.1 & 4.9 & 4.6 \\
\hline & 死亡率 $(\%)$ & 0.5 & 0.7 & 1.2 & 2.0 & 3.4 & 5.3 \\
\hline & 大学進学率 $(\%)$ & - & - & 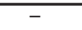 & $\begin{array}{ll}- \\
-\end{array}$ & - & 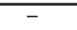 \\
\hline & 年齡(5歳階級) & $60-64$ & $65-69$ & $70-74$ & $75-79$ & $80-84$ & $85-89$ \\
\hline & 未婚率 (\%) & 3.3 & 2.2 & 1.5 & 1.0 & 0.7 & 0.6 \\
\hline & 有配偶率 (\%) & 88.7 & 88.4 & 86.9 & 82.5 & 77.7 & 59.7 \\
\hline & 死別率 (\%) & 3.3 & 5.2 & 8.6 & 13.9 & 18.9 & 37.2 \\
\hline & 離別率(\%) & 4.0 & 3.5 & 2.2 & 1.5 & 1.6 & 1.3 \\
\hline & 死亡率 (\%) & 8.8 & 13.7 & 21.2 & 34.2 & 50.9 & 100.0 \\
\hline & 大学進学率 (\%) & - & - & - & - & - & - \\
\hline \multirow{24}{*}{$\begin{array}{l}\text { 女 } \\
\text { 性 }\end{array}$} & 年齡(5歳階級) & $0-4$ & $\frac{5-9}{2}$ & $10-14$ & $15-19$ & $20-24$ & $25-29$ \\
\hline & 未婚率 (\%) & 100.0 & 100.0 & 100.0 & 98.2 & 84.2 & 46.4 \\
\hline & 有配偶率 (\%) & 0.0 & 0.0 & 0.0 & 1.7 & 14.9 & 50.8 \\
\hline & 死別率 (\%) & 0.0 & 0.0 & 0.0 & 0.0 & 0.0 & 0.1 \\
\hline & 離別率 (\%) & 0.0 & 0.0 & 0.0 & 0.1 & 0.8 & 2.6 \\
\hline & 死亡率 (\%) & 0.1 & 0.0 & 0.1 & 0.1 & 0.1 & 0.2 \\
\hline & 大学進学率 (\%) & - & - & - & 69.1 & - & - \\
\hline & 合計特殊出生率 & - & - & - & 2.8 & 18.9 & 44.9 \\
\hline & 年齡(5歳階級) & $30-34$ & $35-39$ & $40-44$ & $45-49$ & $50-54$ & $55-59$ \\
\hline & 未婚率 (\%) & 20.8 & 10.1 & 6.6 & 4.8 & 4.0 & 3.8 \\
\hline & 有配偶率(\%) & 74.6 & 83.5 & 85.9 & 85.3 & 84.5 & 81.5 \\
\hline & 死別率 (\%) & 0.3 & 0.5 & 1.0 & 2.2 & 4.2 & 7.5 \\
\hline & 離別率 (\%) & 4.2 & 5.5 & 6.0 & 7.3 & 6.8 & 6.7 \\
\hline & 死亡率 (\%) & 0.3 & 0.4 & 0.7 & 1.2 & 1.6 & 2.4 \\
\hline & 大学進学率 (\%) & - & $\overline{-}$ & - & - & - & - \\
\hline & 合計特殊出生率 & 43.3 & 16.8 & 2.3 & 0.1 & - & - \\
\hline & 年齡(5歳階級) & $60-64$ & $65-69$ & $70-74$ & $75-79$ & $80-84$ & $85-89$ \\
\hline & 未婚率 $(\%)$ & 3.4 & 3.8 & 4.0 & 3.9 & 2.8 & 1.4 \\
\hline & 有配偶率(\%) & 77.2 & 68.5 & 56.0 & 35.9 & 20.5 & 8.2 \\
\hline & 死別率 (\%) & 13.5 & 22.1 & 34.4 & 54.2 & 71.4 & 86.5 \\
\hline & 離別率 (\%) & 5.4 & 4.8 & 4.7 & 4.7 & 3.3 & 2.1 \\
\hline & 死亡率 (\%) & 4.1 & 6.4 & 11.7 & 21.3 & 36.3 & 100.0 \\
\hline & 大学進学率 (\%) & - & - & - & - & - & - \\
\hline & 合計特殊出生率 & - & - & - & - & - & - \\
\hline
\end{tabular}

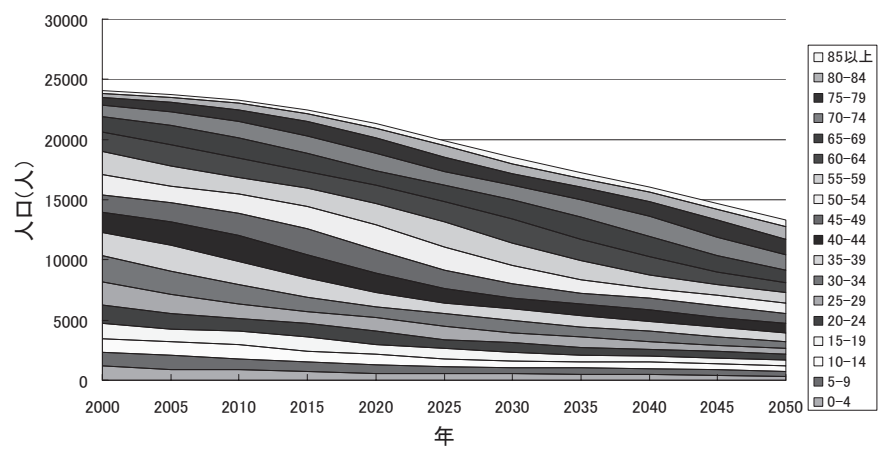

図 3 コーホート要因法による人口推計結果
それぞれ個別に推計し、その結果を合成して将来における人口を推計 する方法である。しかし、5 年齢層毎の人口をひとまとまりとして扱 うため、世帯個々のライフサイクルを考慮した世帯構成人員の推計を 行うことが出来ない。そこで本研究では、コーホート要因法の手法を 応用し、一世帯毎に世帯人員が 5 期毎に成長し、自然増の要因におけ る世帯構成が推移するように年齢層別性別にそれぞれ生存率、死亡率、 結婚率、離婚率および出生率を掛けることで、次期の既存の住宅にお ける世帯人員構成が推計できるようにした。計算条件を表 1 に示す。 $(\mathrm{t}+5)$ 期での出生数を推計するため、合計特殊出生率に 15-49 歳ま での出産可能女性人口を掛けて算出する。なお、合計特殊出生率は、 計量経済モデルより推計される変数である。 $(\mathrm{t}+5)$ 期の総人口は、 $\mathrm{t}$ 期での生存者数と $(\mathrm{t}+5)$ 期の出生数の合計で算出される。結婚に よる転出・転入数は、世帯内で兄弟が結婚した場合、残りの未婚の兄 弟は、転出すると仮定した。その場合、転出先は、重みにより決定す るが、対象地域である駅周辺では、ドーナツ化現象を仮定し、全て他 地域へ転出すると仮定している。また、生活スケジュールが変化する とエネルギー消費量も変化するため、15-19 歳層で進学率を考慮し、 65 歳以上は、高齢者の生活スケジュールになるようにした。

\section{2 人口推計結果}

人口推計結果を図 3 に示寸。初期值では、 24,077 人であったが、 50 年後では 13,286 人と約 $45 \%$ 減少している。また、少子高齢化を 示寸結果として、65 歳以上の年齢層の人口が 50 年後では全体の約 $40 \%$ 占めている。その理由の一つとして、駅周辺の人口増減は、 近年減少傾向にあるため、初期設定として、他地域からの世帯の転入 を考慮していないため、他地域より高齢者が居住する割合が高くなっ た。

\section{4. 計量経済モデル}

\section{1 モデル概要}

モデルは、今期既存世帯数の推移、転出入世帯数の推移および新着 工床面積の推移を推計することが出来る。新築住宅供給棟数は、人 口・世帯部門の変数である新着工床面積推計により推計される。なお、 豊橋市の 1 世帯当りの平均述床面積は、約 $100 \mathrm{~m}^{2}$ であるため、新着工 床面積 100 mあたりで新築住宅が一棟供給されたものと仮定する。モ デルに使用したサンプル期間は、1989-2002 年の 14 年間である。推 定法は直接最小 2 乗法推定（OLS）を用いた。

推定式の有意性を判別するため、 $\mathrm{t}$ 值を 1.0 以上、決定係数及び自 由度修正後決定係数を 0.75 以上、 DW（ダービンワトソン）比を 1 -3 以内、自由度（D F ）を 9 以上の式を採用した。豊橋市計量経済 モデルで使用した推計式を表 2 に示す。変数 20 個（内生変数 12 個、 加工変数 3 個、外生変数 5 個）を使用し、世帯ブロック、人口ブロッ ク、財政ブロック、地価ブロックに分類して、モデルを構築した。構 造方程式の因果序列図を図 4 に変数記号表を表 3 に示す。

人口ブロックは、社会動態（転入人口関数、転出人口関数）、自然 
動態 (合計特殊出生率関数) に関する 5 変数である。世帯ブロックは、 市内全世帯 (市全体世帯関数)、対象地域内世帯（駅周辺世帯関数）、 住宅供給（新着工床面積関数）に関する 3 変数である。財政ブロック は, 歳入関連 4 変数（純家計所得関数、歳入関数、税収関数、豊橋市
内総生産関数)、歳出関連 1 変数 (歳出関数) である。地価ブロック は、地価（駅周辺地価関数）に関する 1 変数である。また、構造方程 式内の外生変数は、コーホート要因法により推計される豊橋市人口、 愛知県人口、全国市街地化指数、愛知県民所得、タイムトレンドの 5

表 2 計量経済モデルによる推計式

\begin{tabular}{|c|c|c|}
\hline \multicolumn{3}{|r|}{ 世帯ブロック } \\
\hline $\begin{array}{c}\text { 駅周辺世帯関数 } \\
\text { NF1 }\end{array}$ & $\begin{array}{c}\text { 推計式 } \\
\mathrm{t} \text { 值 } \\
\text { 判別値 }\end{array}$ & 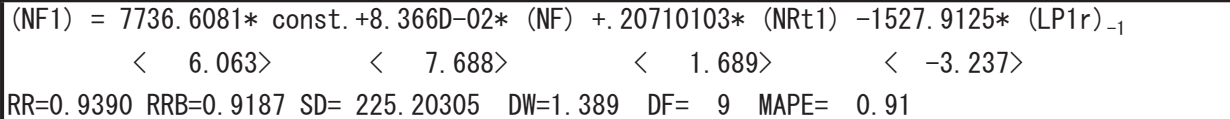 \\
\hline $\begin{array}{c}\text { 市全体世帯関数 } \\
\text { NF }\end{array}$ & $\begin{array}{c}\text { 推計式 } \\
\mathrm{t} \text { 值 } \\
\text { 判別値 }\end{array}$ & $\begin{array}{ccc}(\mathrm{NF})=-3493375.4 * \text { const. } & +6.491 \mathrm{D}-03 *(\mathrm{YTt})_{-1}+1804.8384 *(\mathrm{~T}) \\
\langle-17.692\rangle & \langle 2.302\rangle & \langle 17.951\rangle \\
\mathrm{RR}=0.9968 \mathrm{RRB}=0.9962 \mathrm{SD}=489.12616 \quad \mathrm{DW}=1.441 \quad \mathrm{DF}=10 \quad \mathrm{MAPE}=0.32\end{array}$ \\
\hline $\begin{array}{c}\text { 新着工床面積関数 } \\
\mathrm{NFna}\end{array}$ & $\begin{array}{c}\text { 推計式 } \\
\mathrm{t} \text { 值 } \\
\text { 判別値 }\end{array}$ & 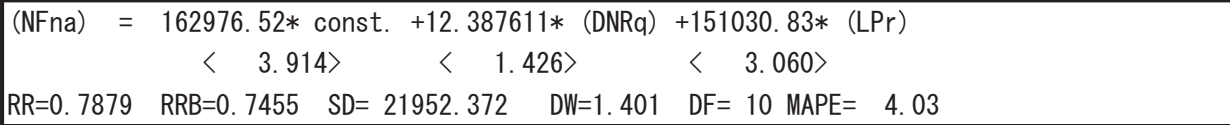 \\
\hline \multicolumn{3}{|r|}{ 人ロブロック } \\
\hline $\begin{array}{c}\text { 転入人口関数 } \\
\mathrm{NI}\end{array}$ & $\begin{array}{c}\text { 推計式 } \\
\mathrm{t} \text { 值 } \\
\text { 判別値 }\end{array}$ & 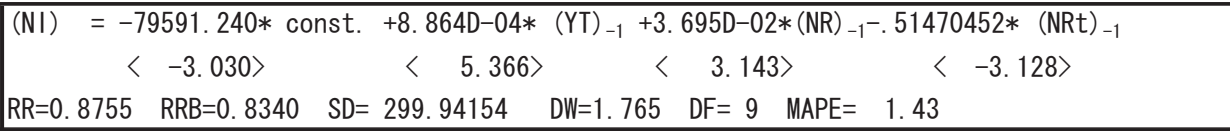 \\
\hline $\begin{array}{c}\text { 転出人口関数 } \\
\text { N0 }\end{array}$ & $\begin{array}{c}\text { 推計式 } \\
\mathrm{t} \text { 值 } \\
\text { 判別値 }\end{array}$ & $\begin{array}{cccc}(\mathrm{N} 0)=2278.6423 * \text { const. } & +.95137882 *(\mathrm{NO})_{-1} & -1.391 \mathrm{D}-02 *(\mathrm{GE})_{-1} \\
& \langle 4.436\rangle & \langle 9.160\rangle & \langle-1.124\rangle \\
\mathrm{RR}=0.9764 & \mathrm{RRB}=0.9717 \quad \mathrm{SD}=187.62305 \quad \mathrm{DW}=1.418 & \mathrm{DF}=10 \quad \mathrm{MAPE}=1.04\end{array}$ \\
\hline $\begin{array}{c}\text { 合計特殊出生率関数 } \\
\mathrm{NBr}\end{array}$ & $\begin{array}{c}\text { 推計式 } \\
\mathrm{t} \text { 值 } \\
\text { 判別値 }\end{array}$ & 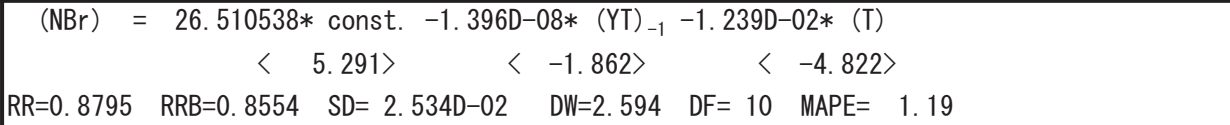 \\
\hline \multicolumn{3}{|r|}{ 財政ブロック } \\
\hline $\begin{array}{l}\text { 家計収入関数 } \\
\text { RETA } \\
\text { (歳入一税収) }\end{array}$ & $\begin{array}{c}\text { 推計式 } \\
\mathrm{t} \text { 值 } \\
\text { 判別値 }\end{array}$ & 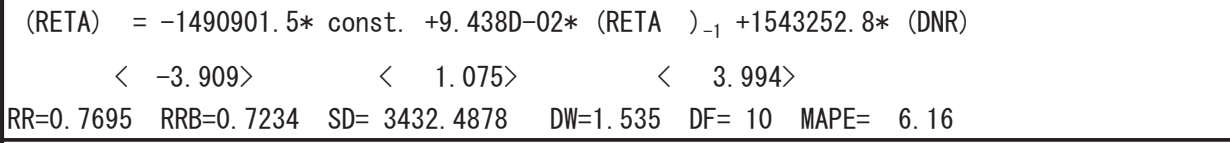 \\
\hline $\begin{array}{c}\text { 歳出関数 } \\
\text { GE }\end{array}$ & $\begin{array}{c}\text { 推計式 } \\
\mathrm{t} \text { 值 } \\
\text { 判別値 }\end{array}$ & 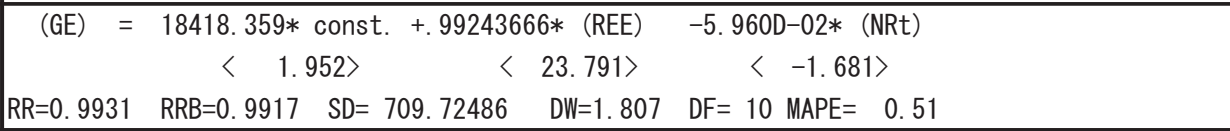 \\
\hline $\begin{array}{c}\text { 税収関数 } \\
\text { TA }\end{array}$ & $\begin{array}{c}\text { 推計式 } \\
\mathrm{t} \text { 值 } \\
\text { 判別值 } \\
\end{array}$ & 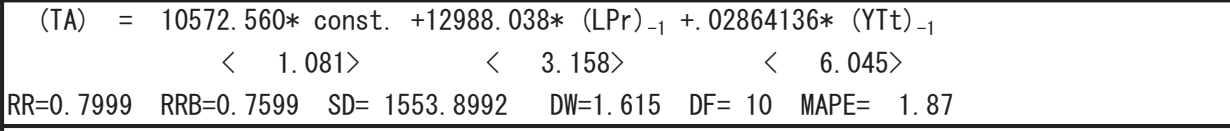 \\
\hline $\begin{array}{c}\text { 豊橋市民所得関数 } \\
\text { YT t }\end{array}$ & $\begin{array}{c}\text { 推計式 } \\
\mathrm{t} \text { 值 } \\
\text { 判別值 } \\
\end{array}$ & 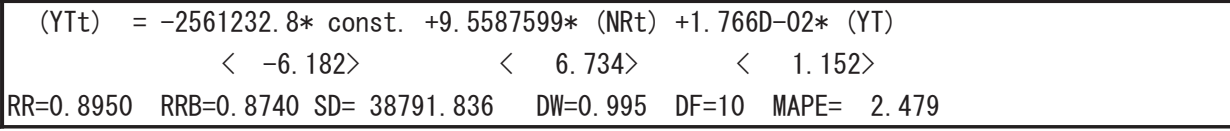 \\
\hline \multicolumn{3}{|r|}{ 地価ブロック } \\
\hline $\begin{array}{c}\text { 駅周辺地価関数 } \\
\text { LP1r }\end{array}$ & $\begin{array}{c}\text { 推計式 } \\
\mathrm{t} \text { 值 } \\
\text { 判別値 }\end{array}$ & $\begin{array}{c}(\mathrm{LP} 1 \mathrm{r})=-.47426918 * \text { const. }+.18757828 *(\mathrm{LP} 1 \mathrm{r})_{-1}+.88603835 *(\mathrm{LPr})_{-1}+4.794 \mathrm{D}-07 *(\mathrm{YTt})_{-1} \\
\langle-1.688\rangle \quad\langle 1.486\rangle \quad\langle\quad\langle\quad\langle .585\rangle \\
\mathrm{RR}=0.9353 \quad \mathrm{RRB}=0.9138 \quad \mathrm{SD}=3.676 \mathrm{D}-02 \quad \mathrm{DW}=1.923 \quad \mathrm{DF}=9 \quad \mathrm{MAPE}=1.71\end{array}$ \\
\hline
\end{tabular}

\begin{tabular}{|l|l|}
\hline \multirow{3}{*}{ 加工式 } & $(\mathrm{DNRq})=(\mathrm{NRt})-(\mathrm{NRt})_{-1}$ \\
\cline { 2 - 3 } & $(\mathrm{DNR})=(\mathrm{NRt})_{-1} /(\mathrm{NRt})$ \\
\cline { 2 - 3 } & 歳入 $(\mathrm{REE})=(\mathrm{RETA})+(\mathrm{TA})$ \\
\hline
\end{tabular}

※const.は定数を表す。変数の添え字-1は、変数の一期ラグを表す。

$R R:$ 決定係数 $=1-($ 誤差変動 $/$ 全変動 $) 、 R R B:$ 自由度修正後決定係数 $=\frac{1-(n-1)}{(n-k-1)}(1-R R) 、 S D:$ 方程式の標準誤差 $=\frac{S S E}{(n-k-1)}$

$D F:$ 自由度 $=n-k-1 、 D W:$ ダービンワトソン比 $=\frac{\sum_{t=2}^{n}\left(e_{t}-e_{t-1}\right)^{2}}{\sum_{t=1}^{n} e_{t}^{2}} 、 M A P E:$ 絶対平均誤差率、 $t$ 值 $=\frac{|X-m|}{\sqrt{\frac{U}{n}}}$

$n:$ サンプル数、 $k$ : 説明変数の個数、 $X:$ 標本平均、 $m:$ 母平均、 $U:$ 不偏分散 
変数である。なお、タイムトレンドは、初期值が 1 で、毎期 1 だけ増 分される線形成長トレンドを想定した変数として与えられる。豊橋市 人口は、コーホート要因法より推計された值を用いる。愛知県人口は、 人口問題研究所が行っているコーホート変化率法により簡易的に 50 年後の人口を行った。全国市街地化指数および愛知県民所得は、愛知 県人口の変化率に連動する值とした。

\section{2 構造方程式の説明}

世帯ブロックの世帯数を表す基本式は以下の通りである。

世帯数 $=f$ (社会要因, 経済要因, 周辺環境要因) …( 1 )

駅周辺世帯関数 NF1 は、豊橋市の人口 NF のシェア関数として説 明できる。今後の豊橋市の地域計量経済モデルを拡張するにあたり、 豊橋市内での他地域連動型モデルを作成する上で、NF 1 は、豊橋市 全体での人口推移に連動し、人口が決定されるため、これが周辺環境 要因であるとみな寸ことが出来る。社会要因の一つである住宅環境効 用は、地価を代理変数として用いることが出来る。そのため、駅周辺 地価伸び率 LP1r は、社会要因とみな寸ことができる。経済要因とし ては、豊橋市民家計所得 YTt を代理変数として用いた。

コーホート要因法で推計された世帯数を基本的には採用するが、 世帯の増減を補正する場合に用いる。駅周辺世帯関数は、地価が増 加するにつれ、世帯数が減少する。これは、地価 LP r 1 が上昇した 場合、駅周辺の地価価值が、商業ベースに転化することを意味して いる。

新着工床面積関数 NFna は、全国市街地地価指数を組み込むこと で全国の社会動向を反映させた住宅供給がなされることを意味する。 人ロブロックの基本的な式は以下の通りである。

今期人口 $(t+5)=$ 前期人口 $(t)+$ 自然人口動態 + 社会人口動態 ・・ (2)

前期人口は、コーホート要因法より推計された人口を採用する。 自然人口動態では、出生数を推計するために必要な合計特殊出生率 をタイムトレンドと愛知県民所得より説明している。いずれも、負 の要因として方程式に影響している。社会人口動態を表す式は以下 の通りである。

社会流入 $=f($ (口口規模, 経済要因) ...(3) 社会流出 $=f$ (経済要因,定着傾向)$$
\text { ・. (4) }
$$

社会流入は、愛知県および豊橋市の人口動態と愛知県民所得によ り説明される。今期の豊橋市の転入人口は、前期の愛知県人口 (NR) ${ }_{-1}$ の増加に伴い増加にするが、前期の豊橋市人口 $(\mathrm{NR})$ - $_{1}$ 方増加する場 合は転入人口増加率が減少する方程式となった。これは、豊橋市が 人口増加傾向にある場合、転入人口に制限がかかることを意味して いる。しかし、社会流入の方程式の $\mathrm{t}$ 值から判断すると、愛知県の 人口規模要因のほうが、豊橋市の人口規模要因より若干説明力を持 っているため、結果的に愛知県の人口増加に伴い、転入人口が決定 される。社会流出での定着傾向は、流出の一期ラグにより説明した。
財政ブロックは、歳入と歳出の両方から検討できるようになってい る。全体的に制度式を用いて検討した。

個別歳入 $=f \quad$ (税源, 財源規模 $)$
個別歳出 $=f \quad$ (行政需要, 財源规模)

歳入 REE は、家計所得と総税収入との合計であり、家計所得は、 財源規模として、人口関連の変数を使用し、家計所得の 1 期ラグによ り説明した。税収は、本来、市民税、不動産税やタバコ税などのその 他税徵収金から成り立っているが、主として、市民税と不動産税から 成り立っているため、市民税の代理変数として、市民所得 YTt、不動 産税の代理変数として、地価変数 LPrにより推定した。

歳出関数は、行政需要を歳入 REE、財源規模の代理変数として人 口変数を使用し、推定させた。

地価ブロックでの地価の付值の要因として式は、以下の通りである。 地価 $=f \quad$ (周辺地価, 社会要因) $\cdot \cdot(7)$

対象地域の地価である駅周辺地価 LPr1 は、前期の対象地価と全体 の動向を表す全国市街地地価指数変数 LPr と社会的要因の代理変数 として、市民所得 YTt の動向により説明した。

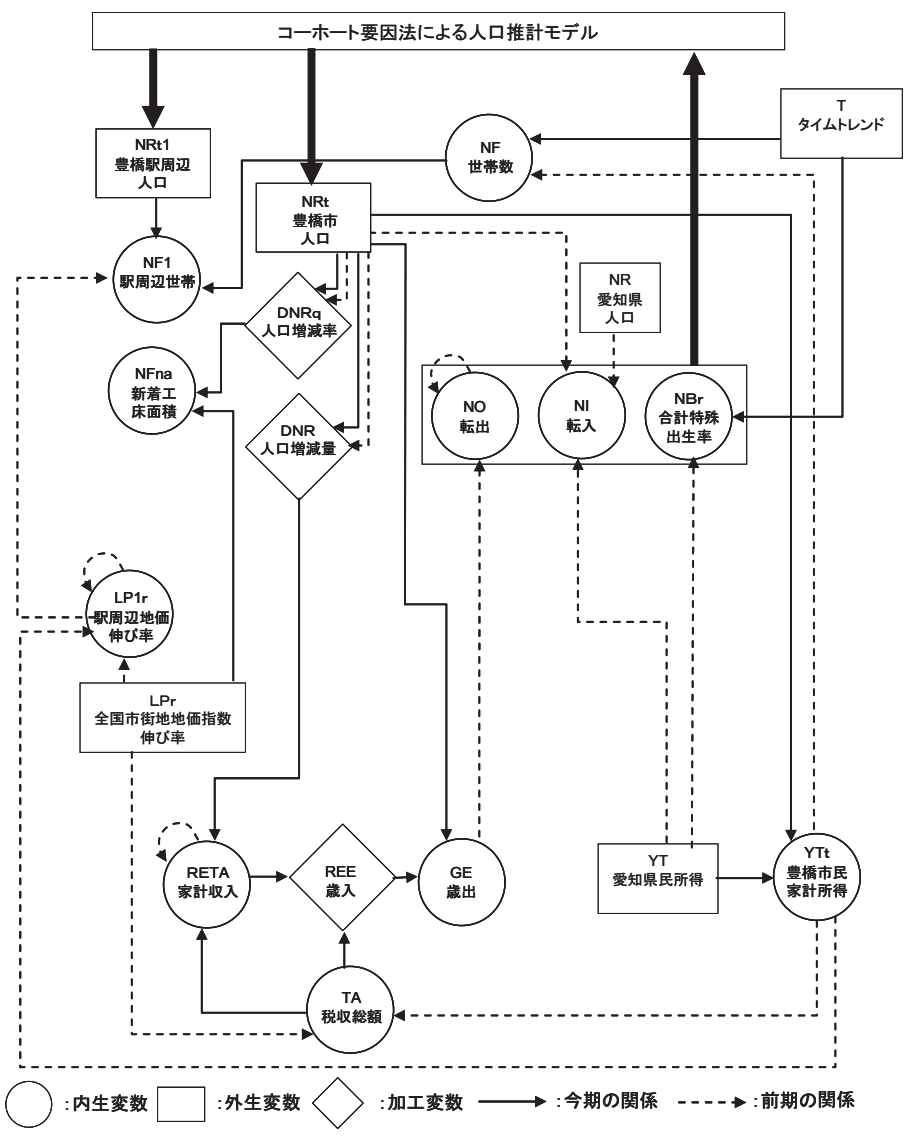

図 4 計量経済モデル因果序列図

表 3 変数記号表

\begin{tabular}{|c|c|c|c|c|c|}
\hline 内生 & 内容 & 内生 & 内容 & 外生 & 内容 \\
\hline NI & 転入 (人) & $\mathrm{YTt}$ & 豊橋市民所得（百万円） & $\mathrm{NR}$ & 愛知県人口 (人) \\
\hline NO & 転出（人） & GE & 歳出総額（百万円） & NRt & 口 (人) \\
\hline $\mathrm{NBr}$ & 合計特殊出生率 & REE & 歳入総額（百万円） & $\mathrm{NF}$ & 士帯総数（戸) \\
\hline NRt1 & 駅周辺人 & TA & 税収総額（百万円） & YT & 愛知県民所得（百万円） \\
\hline NF1 & 駅周辺世帯数（戸） & LP1r & |駅周辺地価伸ひ率 (-) & LPr & 全国市街地地価指数伸び率 (-) \\
\hline $\mathrm{NFn}$ & 住宅新着工床面積（m & & & & ド（西) \\
\hline
\end{tabular}




\section{3 内挿シミュレーションによる検証}

豊橋市計量経済モデル全体の適合結果を確認するため、推定期間の 1989-2002 年の全期間にわたって内扱シミュレーションを行った。

検証の結果一覧を表 4 、表 5 に示す。

内挿シミュレーションの結果、全構造方程式の実現值とファイナ ルテスト值の相関係数 R は、 0.87 以上の值をとり、平均絶対誤差率 MAPE は、全て $10 \%$ 以下であった。家計収入 RETA の MAPE が、 $8.23 \%$ と他と比べて高い值を示しているが、決定係数が 0.8 以上確保 されているため、問題は無い。全体的には、变数の符号も正しい説明 がつき、豊橋市の社会構造を表現できていると判断した。

5. エネルギーマップの作成 エネルギーマップ作成のフローチャー 卜を図 5 に示す。地図データを Microsoft Excel 上で $10 \mathrm{~m}$ 角メッシュ としてVisual Basicにより作成し、地域計量経済モデル及びコーホ 一ト要因法を用いた人口推計モデルをエクセルマップに組み込むこ とにより、住宅のエネルギー推計の将来的な動向の把握を試みた。地 域計量経済モデルは、統計量を基に、同時方程式により推計式を算出 するため、得たい構造方程式の統計量がある場合、部分的な経済シス テムを再現することで推計式を得ることが容易である。また、コーホ 一ト要因法は、人口の社会増と自然増を切り離して推計できるため、 各要因が計量経済モデルの構造方程式に組み込みやすい。エネルギー マップをExcel で作成することで、より汎用性のあるソフトの開発が 可能である。

\section{1 対象地域}

対象地域は、豊橋市の JR 豊橋駅周辺(北緯 $34^{\circ} 45^{\prime}-34^{\circ} 46^{\prime}$ 、東 経 $\left.137^{\circ} 23^{\prime}-137^{\circ} 24^{\prime}\right)$ の $1.55 \mathrm{~km} \times 1.85 \mathrm{~km}$ の範囲である。メッシュ

表 4 ファイナルテスト結果の要約表

\begin{tabular}{|c|c|c|c|c|c|}
\hline $\mathrm{R} / \mathrm{MAPE}$ & $1 \%$ 以下 & $1-3 \%$ & $3-5 \%$ & $5-10 \%$ & 計 \\
\hline 0.97 以上 & 4 & & & & 4 \\
\hline $0.95-0.97$ & & 1 & & & 1 \\
\hline $0.90-0.95$ & & 3 & & & 3 \\
\hline 0.9 以下 & & 2 & & 1 & 3 \\
\hline 合計 & 4 & 6 & & 1 & 11 \\
\hline
\end{tabular}

$\mathrm{R}:$ 実現値とファイナルテスト值の相関係数

MAPE : 平均絶対誤差率、誤差率 (誤差/実現値)の絶対值の平均

表 5 ファイナルテスト結果のまとめ

\begin{tabular}{|l|r|r|r|r|r|r|}
\hline Name & R & Mean(Y) & Mean(YH) & RMS(e) & MAPE & MAPE(3) \\
\hline NF1 & 0.9967 & 18321.54 & 18321.538 & 61.506 & 0.27 & 0.15 \\
NF & 0.9984 & 117053.1 & 117053.077 & 428.992 & 0.32 & 0.17 \\
NFna & 0.8876 & 363664.3 & 363664.308 & 19253.504 & 4.03 & 1.97 \\
NI & 0.9357 & 13908.54 & 13908.538 & 249.566 & 1.43 & 1.17 \\
NO & 0.9881 & 12477 & 12477.000 & 164.556 & 1.04 & 0.65 \\
NBr & 0.9378 & 1.443077 & 1.443 & 0.222 & 1.19 & 2.32 \\
RETA & 0.8772 & 44487.23 & 44487.231 & 3010.491 & 6.16 & 8.23 \\
GE & 0.9965 & 101446.9 & 101446.923 & 622.470 & 0.51 & 0.61 \\
TA & 0.8944 & 60509.62 & 60509.615 & 1362.860 & 1.87 & 1.27 \\
LP1r & 0.9671 & 1.378385 & 1.378 & 0.306 & 1.71 & 1.76 \\
Ytt & 0.9461 & 1258632 & 1258632.307 & 34022.692 & 2.47 & 2.7 \\
\hline
\end{tabular}

(ファイナルテスト結果まとめの見方)

Name : 変数記号

$\mathrm{R} \quad$ : 実現値とファイナルテスト值の相関係数

$\operatorname{Mean}(\mathrm{Y})$ : : 実現値の平均

Mean $(\mathrm{YH}):$ : 理論(ファイナルテスト)值の平均

$\mathrm{RMS}(\mathrm{e}) \quad:$ 誤差の平方和平均の平方根

MAPE : 平均絶対誤差率、誤差率(誤差/実現值)の絶対值の平均

$\mathrm{MAPE}(3)$ : 最終3力年平均絶対値誤差率

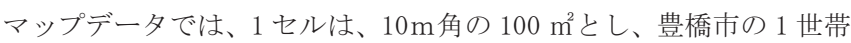
当り延べ面積 $98.0 \mathrm{~m}^{2}$ (参照: 平成 12 年 度豊橋統計書) と対応させ た(図 6)。総計算セル数は、28, 675 セルである。

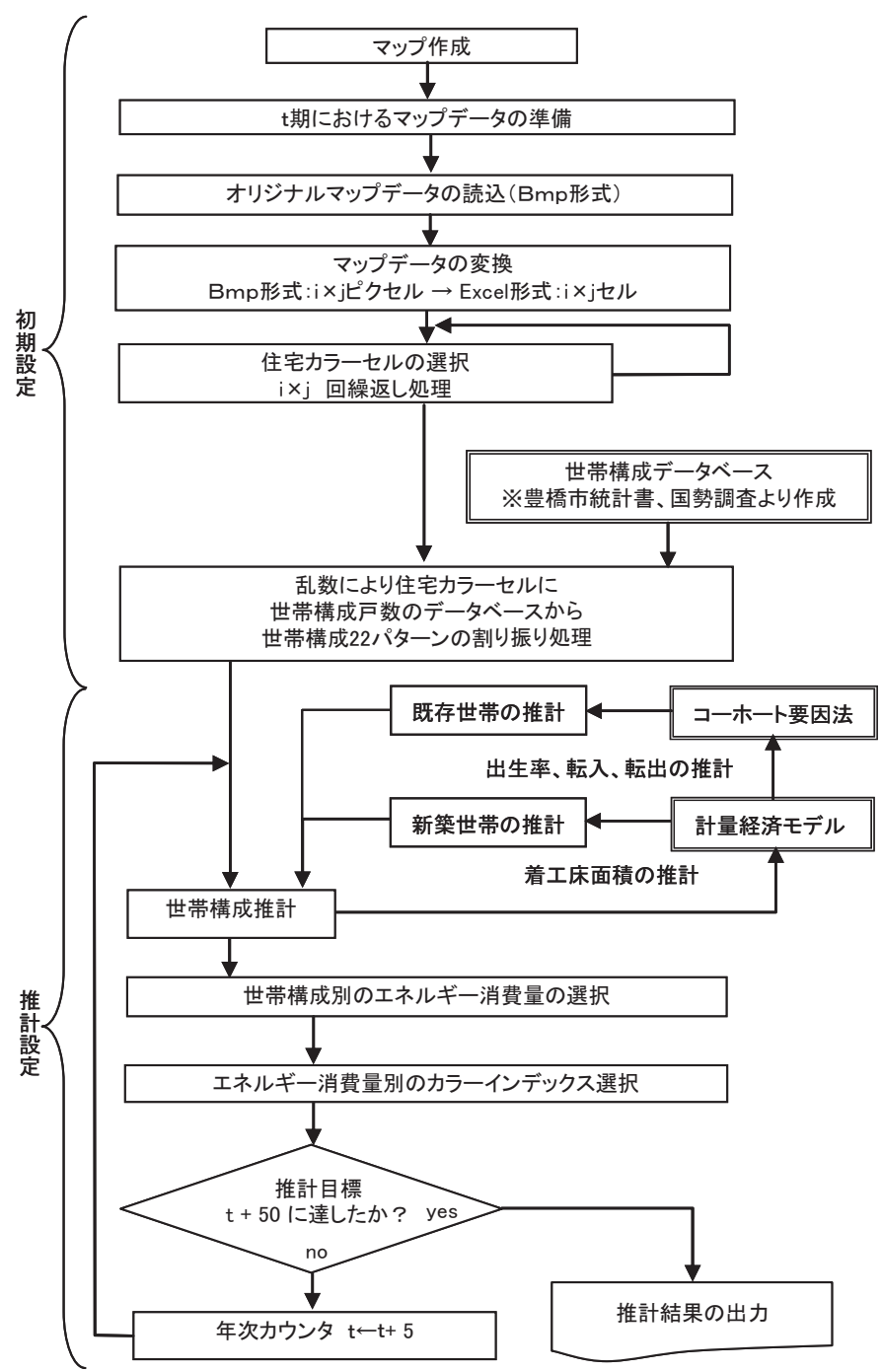

図 5 エネルギーマッピングフローチャート

155 セル

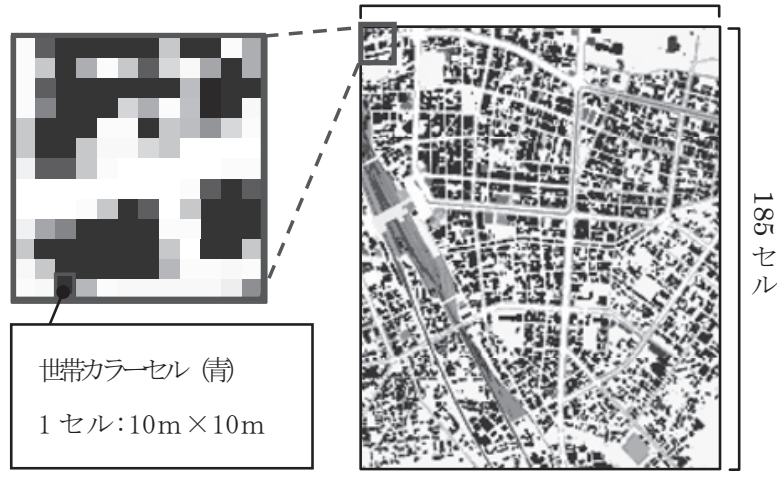

図 6 世帯毎のライフサイクルマトリクス計算 


\section{2 初期值マップの設定}

初期設定として、Exce1で計算マップを作るために対象地域の画像 データ（JPEG形式やGIF形式）をレンダリングし、ビットマップ形式 $(155 \times 185$ ピクセル) に変換する。そして、各ピクセルのビット数 からRGBの数值を読み取り、Exce1のセルに与えることでカラーリング 処理を行う。世帯カラーセル（青）に、豊橋市統計書 ${ }^{10)}$ を基に作 成した世帯データベースを乱数により、ナンバリングする。その与え られた番号により、世帯構成人員として小学生、中学生、勤め人、主 婦、高齢者を組み合わせた世帯構成 22 パターンが割り振られる。

表 5 世帯人員構成別一次消費エネルギー量

\begin{tabular}{|c|c|c|c|c|c|}
\hline \multirow{2}{*}{\multicolumn{2}{|c|}{ 世帯パタ }} & \multirow{2}{*}{ 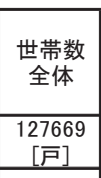 } & \multirow{2}{*}{ 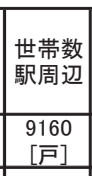 } & \multirow{2}{*}{ 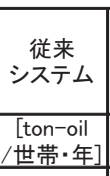 } & \multirow{2}{*}{\begin{tabular}{|c|} 
省エネルギー゙ \\
[従来システムム \\
*0.58] \\
[ton-oil \\
$/$ 世帯·年] \\
\end{tabular}} \\
\hline & & & & & \\
\hline 老 & & 6528 & 533 & 1855 & 1076 \\
\hline 大 & ח & 26208 & 2030 & 1720 & 998 \\
\hline 大大(親子) & & 1564 & 0 & 1855 & 1076 \\
\hline 子大 & & 1199 & 169 & 1904 & 1104 \\
\hline 大老 & & 1284 & 295 & 2453 & 1423 \\
\hline 老老 & & 9080 & 528 & 2168 & 1257 \\
\hline 大大(夫婦) & & 14303 & 1743 & 2049 & 1189 \\
\hline 子子大 & ํํํํำ & 1625 & 166 & 2248 & 1304 \\
\hline 大大老 & & 4970 & 214 & 2527 & 1466 \\
\hline 大大大 & & 4136 & 723 & 2320 & 1345 \\
\hline 子大大 & ํำ & 8073 & 463 & 2251 & 1306 \\
\hline 子大大老 & \begin{tabular}{|lll}
0 & 0 \\
\end{tabular} & 429 & 16 & 2648 & 1536 \\
\hline 大大老老 & 90 & 3762 & 175 & 2485 & 1441 \\
\hline 大大大老 & 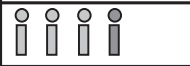 & 360 & 142 & 2485 & 1441 \\
\hline 大大大大 & 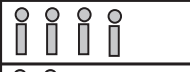 & 10644 & 578 & 2454 & 1423 \\
\hline 子子大大 & ㅇํํำ & 20776 & 827 & 2628 & 1524 \\
\hline 子子大大老 & 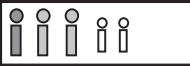 & 721 & 151 & 2992 & 1735 \\
\hline 大大大大老 & 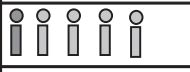 & 2957 & 159 & 2679 & 1554 \\
\hline 子子大大大 & 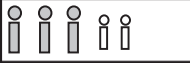 & 2854 & 46 & 2878 & 1669 \\
\hline 大大大大老老 & 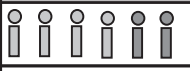 & 1112 & 43 & 2842 & 1649 \\
\hline 子子大大大大 & 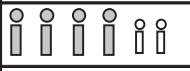 & 3924 & 23 & 2892 & 1677 \\
\hline 子子大大老老 & 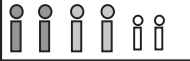 & 1158 & 136 & 3010 & 1746 \\
\hline
\end{tabular}

○:0 歳-19 歳及び 20-25 歳までの就学者

○ : 20-65 歳（20-25 歳までの就業者を含む）

○:65 歳以上

\section{3 推計マップ}

$(\mathrm{t}+5)$ 期における世帯セル毎の世帯構成は、コーホート要因法 および計量経済モデルよりライフサイクルの概念を基に成長し、決定 される。各世帯セルは, 世帯構成員別消費エネルギー（表 5） 22 パタ ーンを消費エネルギー量別のカラーインデックスに置き換え、エネル ギーマップを作成する。世帯人員別一次エネルギー消費量算出するに あたり、年齢別生活スケジュール (小学生、中学生以上の学生、勤め 人、主婦、高齢者）をNHK国民生活時間調查により作成し、それを基 に使用家電消費電力・給湯使用量・冷暖房負荷から建物の運用段階で のエネルギー消費量を算出した。熱負荷計算ソフトSMASHにより冷暖 房負荷を算出している。省エネルギーシステムを導入した住宅 (全電 化システム、自然冷媒ヒートポンプ式電気給湯機 $(\mathrm{COP}=3)$ 、屋上緑 化の導入、ソーラーパネルの使用、トップランナー家電の使用）は、 従来システムより $42 \%$ 消費エネルギー削減効果がある注2）上仮定し、 計量経済モデルにより推計される新着工床面積は、新たに供給される 住宅とみなし、省エネルギーシステムを導入した住宅として配置され る。なお、豊橋市におけるケーススタディの前提条件として、豊橋市

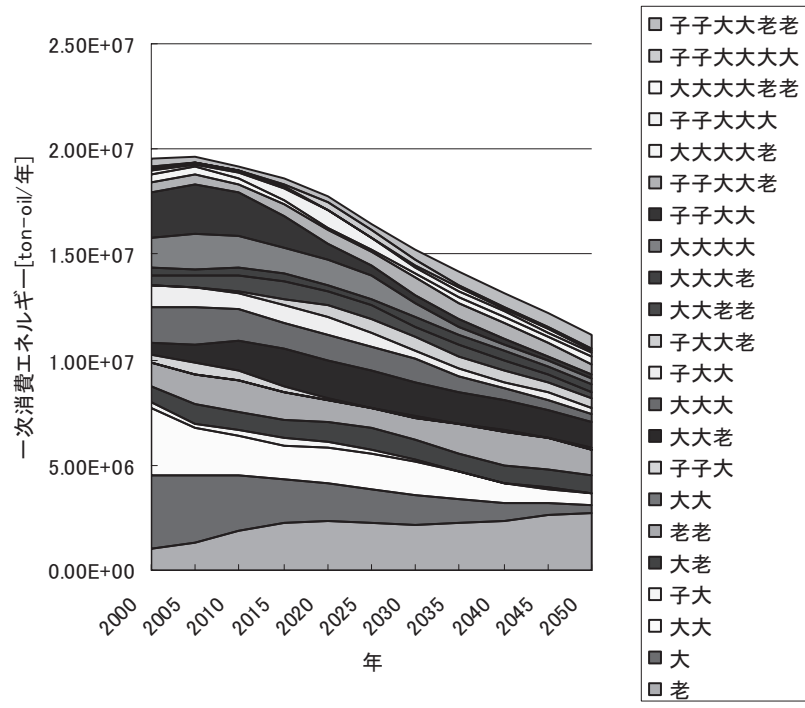

図 7 世帯人員構成別消費エネルギー推計結果

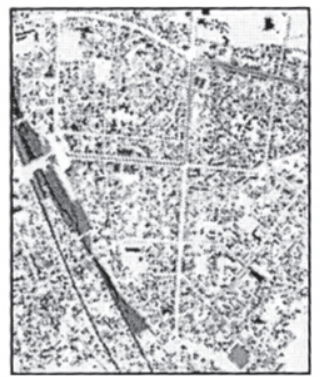

2000 世帯数:9160

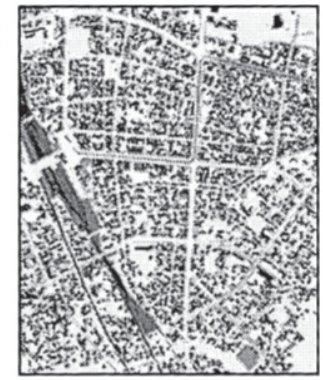

2050 世帯数:4979
図 8 エネルギーマップによる世帯の推移 [ton-oil/年] $14 \times 10^{5} \sim 15 \times 10^{5}$ $13 \times 10^{5} \sim 14 \times 10^{5}$ $12 \times 10^{5} \sim 13 \times 10^{5}$ $11 \times 10^{5} \sim 12 \times 10^{5}$ $10 \times 10^{5} \sim 11 \times 10^{5}$ $9 \times 10^{5} \sim 10 \times 10^{5}$ $9 \times 10^{5} \sim 10 \times 10^{5}$
$8 \times 10^{5} \sim 9 \times 10^{5}$ $7 \times 10^{5} \sim 8 \times 10^{5}$ $6 \times 10^{5} \sim 7 \times 10^{5}$ $5 \times 10^{5} \sim 6 \times 10^{5}$ $4 \times 10^{5} \sim 5 \times 10^{5}$ $4 \times 10^{5} \sim 5 \times 10^{5}$ $3 \times 10^{5} \sim 4 \times 10^{5}$ $1 \times 10^{5} \sim 2 \times 10^{5}$ $1 \times 10^{5} \sim 2 \times 10^{5}$ 
の約 12 万世帯中 9 万 7 千世帯という全体の約 $80 \%$ が、2 階以下の低層 住居であるため、全てを戸建住宅として想定し、世帯セルはすべて日 本建築学会標準住宅と仮定しているため、高層アパートは考慮してい ない。

\section{6 エネルギ一推計結果}

50 年後のエネルギー推計結果とエネルギーマップを図 7、図 8 に 示寸。駅周辺の地域における一次消費エネルギー石油換算注 3 ) で初期 值 $1.96 \times 10^{7} \mathrm{ton} /$ 年から、 5 年後に $1.97 \times 10^{7} \mathrm{ton} /$ 年とピークに達し、 2050 年に $1.12 \times 10^{7}$ ton/年と約 $43 \%$ 減少している。世帯人員構成か ら検討を行うと、老人単身世帯, 老夫婦世帯及び夫婦十高齢者片親世帯

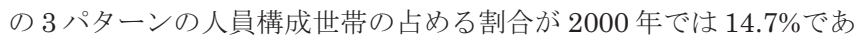
ったが,2050 年では $46.3 \%$ となった。

エネルギーマップから、駅周辺では空洞化が著しく表れ、少子高齢 化社会を反映するような結果となった。

\section{7 まとめ}

5 年度毎の住宅の消費エネルギーの推移を地図上で把握するため に、コーホート要因法や計量経済モデルを用いてエネルギーマップに 関する基礎的モデルの開発を行い、以下の知見を得た。

1）ライフサイクルを考慮したコーホート要因法で発生しうる家族 構成パターンを生活スケジュールに基づき、22 パターンに整理 した。

2） 1 世帯ごとにコーホート要因法を応用した生存・結婚・出産の確 率モデルを適用することで人口を推計した。2000 年度を初期值 とする 50 年後の推計結果では、少子高齢化社会が導き出され、 高齢者世帯が全世帯数の約 $46 \%$ を占める結果となった。

3）豊橋市の社会動向を取り入れるため、計量経済モデルの開発を 行い、新着工戸数の推計およびコーホート要因法に必要な変数 の推計を行った。

4） Excel をベースに画像変換することにより、画像データを計算領 域とするマップモデルを開発した。

今後の課題として、市全体のモデルを完成させ、交通便益による住 宅供給量の検討を行うため、交通モデルの構築、階高方向への消費エ ネルギー集約を把握するために高層住居建築を考慮し、かつ住宅の開 発地域を誘導するマップモデルの開発を行う必要がある。エネルギー 原単位を 2000 年度のものを使用したが、将来のエネルギー原単位の 変化を考慮すべく、省エネルギー技術革新に関するパラメータを取り 入れたモデルを考慮する必要がある。また、住宅のみならず民生部門 全体でのエネルギー推計をするにあたり、業務ビルエネルギー推計モ デルを構築する必要がある。

\section{謝辞}

本研究の一部は、豊橋技術科学大学 21 世紀 C O E 拠点形成プログ ラム「未来社会の生態恒常性工学」によるものである。また、地域計 量経済モデルを構築するに当り、本学人文・社会工学系 山口誠教授 のご指導に対し、感謝の意を表します。

注

注 1）女性が出産可能な年齢を 15 歳から 49 歳までと規定し、それぞれの出生 率を出し、足し合わせることで、人口構成の偏りを排除し、一人の女性 が一生に産む子供の数の平均のことである。

注 2）従来システムは、電力のエネルギー消費効率 $35 \%$ 、ガスのエネルギー消 費効率 $78 \%$ とし、断熱材厚さ $50 \mathrm{~mm}$ 、暖房設定温度 $20^{\circ} \mathrm{C}$ 、冷房設定温 度 $26^{\circ} \mathrm{C}$ 、給湯出口温度を入浴で $42^{\circ} \mathrm{C} 、$ シャワー・キッチンで $38^{\circ} \mathrm{C}$ 、照 明は蛍光灯 $72 \mathrm{~W}$ 、白熱灯 $60 \mathrm{~W}$ と仮定した。一方、省エネルギーシステム は、エネルギー消費量削減に重点をおいた設定をしており、断熱材厚さ $200 \mathrm{~m}$ m、暖房設定温度 $17^{\circ} \mathrm{C}$ 、冷房設定温度 $29^{\circ} \mathrm{C}$ 、給湯出口温度を入浴

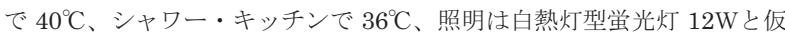
定した。給湯システムは、自然冷媒ヒートポンプ式電気給湯機とし、成 績係数 3 とした $(\mathrm{COP}=3)$ 。屋上緑化の導入として、計算に用いた芝の 等価的熱抵抗值は、冬期 $0.88 \mathrm{~m}^{2} \mathrm{~K} / \mathrm{W}$ 、夏期 $0.33 \mathrm{~m}^{2} \mathrm{~K} / \mathrm{W}$ とした。ソーラ 一パネルは定格出力 $4.16 \mathrm{~kW} 、$ イン゙ータ効率 0.92 とした。

注 3) 石油の一次エネルギー換算係数は、1TOE(Ton- Oil-Equivalent) $=41.868$ GJ とした。

\section{参考文献}

1）藤野純一，甲斐沼美紀子，松岡譲，松井重和：AIM-Trend モデルを用い たアジア各国別エネルギー需給予測シナリオの開発，エネルギーシステ ム・経済·環境コンファレンス講演論文集, 657-662, 2002

2) 山口誠: 北関東自動車道整備効果の計量経済学的分析 杤木県地域の分割 モデルによる地域経済への影響把握，地域学研究(つくば) Vol.27, No.1, 37-50, 1997

3）山口誠，鯉江康正，石川隆司：自動車交通による環境変化が地域社会経済 に与えるインパクトの計量経済学分析, 日本地域学会地域学研究,第 22 巻, $1-15,1992$

4）酒井潤，佐藤仁美，奥宮正哉，田中英紀：GIS を用いた地域エネルギー 利用計画に関する研究 その 1 大垣市における未利用エネルギー活用の 可能性検討, 日本建築学会大会学術講演梗概集 D-1, 505-506, 2005

5) 草刈洋行, 須藤諭, 川村広則：東北 6 県の各駅周辺地域における地域工 ネルギー消費特性の評価に関する研究 地理情報システムを用いた地域 エネルギー消費特性の評価 その 3 , 日本建築学会大会学術講演梗概集 D-1, 733-734, 2006

6）木村竜士,松本博：都市におけるエネルギーフローのシステムモデルに関 する研究 その $2 \mathrm{SD}$ 法による人口変動に伴うエネルギー損失動向の予測 日本建築学会大会学術講演梗概集 D-1, 617-618, 2004

7） 木村竜士,松本博：都市におけるエネルギーフローのシステムモデルに関 する研究その 5 豊橋市の住宅地を対象とした世帯主推計連動型簡易モ デルによるエネルギーフロー, 空気調和・衛生工学会学術講演会講演論文 集, 2185-2188, 2006

8）福井浩喜,三宅醇,谷武：世帯主年齢,世帯収入,住宅所有関係別からみた最 低居住水準の分析愛知県におけるケーススタディー, 日本建築学会大会 学術講演梗概集 F-1, 1213-1214, 2003

9) Hiroshi Matsumoto, Ryushi Kimura, Yoshinori Fujita and Yu Fat Lun : Embodied energy consumption of buildings based on the input-output analysis, IBPSA Australasia, 2006

10) 豊橋市,豊橋統計書 平成元年版(1990)～平成 14 年版(2003) 